\title{
FEATURES OF THE DECIDUALIZED ENDOMETRIOSIS DIAGNOSIS AND COURSE DURING PREGNANCY
}

Gerasimova $A A^{1,2}$, Asyrafyan $L A^{3}$, Manuchin $I^{4}$, Shamarakova $\mathrm{MV}^{2}$, Miryasova MS ${ }^{5}$, Klimenko $\mathrm{PA}^{6} \square$

${ }^{1}$ Peoples' Friendship University of Russia, Moscow, Russia

${ }^{2}$ Family Planning and Reproduction Center, Moscow, Russia

${ }^{3}$ Kulakov National Medical Research Center for Obstetrics, Gynecology and Perinatology, Moscow, Russia

${ }^{4}$ Yevdokimov Moscow State University of Medicine and Dentistry, Moscow, Russia

${ }^{5}$ Sechenov First Moscow State Medical University, Moscow, Russia

${ }^{6}$ Pirogov Russian National Research Medical University, Moscow, Russia

\begin{abstract}
Currently, surgical treatment aimed to exclude the malignant ovarian tumors is performed in almost $90 \%$ of patients with decidualized endometrial cysts (DEC). However unnecessary surgical interventions increase the risk to maternal and fetal health. The study was aimed to perform a differential diagnosis of DEC in pregnant women in order to define the rational treatment. A total of 82 female patients were included in the study: 63 had endometrial cysts (EC), 16 had DEC, 3 had rare forms of endometriosis, and 10 had ovarian serous papillary borderline tumors. When performing the diagnostic ultrasound, our proposed model was used. The ultrasound imaging data obtained were juxtaposed with the concentration of the protein tumor markers (CA-125), the risk of malignancy index (RMI) was calculated, and the morphological assessment of the masses was performed. The ultrasound imaging parameters, being the most valuable for differential diagnosis of EC, DEC, and serous borderline tumors, were as follows: the altered mass wall thickness, the existence and shape of papillary masses, avascular echogenic inclusions with blurry contour, blood circulation and arrangement of blood vessels, ascites. The frequency analysis revealed the differences between groups based on the ultrasound imaging data (in $60-100 \%$ of observations). Histological examination revealed the differences between groups in $100 \%$ of observations. Our findings have made it impossible to prolong pregnancy in patients with DEC without performing surgery. The results of treatment provided to patients with DEC during pregnancy were worse compared to those in patients with no prominent decidualization in ovarian EC. Today, the diagnosis of DEC and the treatment of patients during pregnancy remain unsophisticated. Further clinical observation and the search for more reliable methods of the diagnosis and rational treatment of pregnant women with DEC are required.
\end{abstract}

Keywords: ultrasound examination, morphological analysis, ovarian tumors, pregnant women

Author contributions: the authors contributed to the study and preparation of the article equally, they read and approved the final version of the article prior to publication.

Compliance with ethical standards: the study was approved by the Ethics Committee of Pirogov Russian National Research Medical University (protocol № 176 dated June 25, 2018). The informed consent was submitted by all patients.

$\triangle$ Correspondence should be addressed: Pyotr A. Klimenko

Sevastolopsky prospect, 24a, Moscow, 117209, Russia; pa.klimenko@mail.ru

Received: 23.11.2021 Accepted: 06.12.2021 Published online: 12.12.2021

DOI: $10.24075 /$ brsmu.2021.059

\section{ОСОБЕННОСТИ ДИАГНОСТИКИ И ТЕЧЕНИЯ ЭНДОМЕТРИОЗА С ДЕЦИДУАЛЬНЫМ МЕТАМОРФОЗОМ ВО ВРЕМЯ БЕРЕМЕННОСТИ}

\author{
А. А. Герасимова ${ }^{1,2}$, Л. А. Ашрафян ${ }^{3}$, И. Б. Манухин ${ }^{4}$, М. В. Шамаракова², М. С. Мирясова \\ Российский университет дружбы народов, Москва, Россия \\ 2 Центр планирования семьи и репродукции, Москва, Россия \\ ${ }^{3}$ Национальный медицинский исследовательский центр акушерства, гинекологии и перинатологии имени В. И. Кулакова, Москва, Россия \\ ${ }^{4}$ Московский государственный медико-стоматологический университет имени А. И. Евдокимова, Москва, Россия \\ 5 Первый Московский государственный медицинский университет имени И. М. Сеченова, Москва \\ ${ }^{6}$ Российский национальный исследовательский медицинский университет имени Н. И. Пирогова, Москва, Россия
}

\begin{abstract}
В настоящее время при наличии децидуализированных эндометриоидных кист яичников (ДЭК) хирургическое лечение для исключения злокачественных опухолей яичников выполняют практически в 90\% случаев. Неоправданные хирургические вмешательства при этом увеличивают риск для здоровья матери и плода. Целью исследования было провести дифференциальную диагностику ДЭК у беременных для определения рационального лечения. В исследование включены 82 пациентки: 63 из них были с эндометриоидными кистами (ЭК), 16 - с ДЭК, 3 - с редкими формами эндометриоза и 10 - с серозными папиллярными пограничными опухолями яичников. Для ультразвуковой (УЗ) диагностики использовали предложенную авторами модель. Полученные УЗ-данные сопоставляли с концентрацией белка-онкомаркера (CA-125), рассчитывали индекс RMI (risk of malignancy index), выполняли морфологическое исследование образований. Особо ценными УЗ-параметрами при дифференциальной диагностике ЭК, ДЭК и пограничных серозных опухолей были: измененная толщина стенки образования, наличие и форма папиллярных образований, аваскулярные эхогенные включения без четких контуров, кровоток и расположение сосудов, асцит. Результаты частотного анализа показали различия между группами по данным УзИ (в 60-100\% наблюдений). Гистологическое исследование выявило различие между группами в 100\% наблюдений. Полученные результаты не позволили нам пролонгировать беременность при ДЭК без выполнения хирургического лечения. Результаты лечения пациенток с ДЭК во время беременности были хуже таковых без выраженной децидуальной трансформации ЭК яичников. В настоящее время диагностика дЭК и лечение больных во время беременности остаются несовершенными. Необходимы дальнейшие клинические наблюдения и поиск более надежных способов диагностики и рационального лечения беременных с ДЭК.
\end{abstract}

Ключевые слова: ультразвуковое исследование, морфологическое исследование, опухоли яичников, беременность

Вклад авторов: авторы внесли равнозначный вклад в проведение исследования и подготовку статьи, прочли и одобрили ее финальную версию перед публикацией.

Соблюдение этических стандартов: исследование одобрено этическим комитетом РНИМУ им. Н. И. Пирогова (протокол № 176 от 25 июня 2018 г.). Все пациенты подписали информированное согласие на участие в исследовании.

$\triangle$ Для корреспонденции: Петр Афанасьевич Клименко

Севастопольский проспект, д. 24а, г. Москва, 117209, Россия; pa.klimenko@mail.ru

Статья получена: 23.11.2021 Статья принята к печати: 06.12.2021 Опубликована онлайн: 12.12.2021

DOI: $10.24075 /$ vrgmu.2021.059 
Ovarian endometriosis is a chronic tumor-like lesion observed in $1-2 \%$ of pregnant women [1]. In $12 \%$ of women, the foci of endometriosis may undergo decidualization, and emerge as early as at 9 weeks of gestation [2].

Decidualization is a benign transient lesion, observed during gestation. It is usually found during the caesarian section or surgical treatment of masses with high risk of malignization. The decidual regression occurs in 4-6 weeks after delivery [3]. According to some reports, lower levels of decidualization in the postpartum period [4] are associated with high progesterone levels, absence of menstrual periods, and increased apoptosis being the key factor of endometriosis regression.

Decidualized endometrial cysts (DEC) are almost always asymptomatic during pregnancy. When performing the ultrasound examination of DEC, the majority of authors distinguish the combination of the cystic cavity with a large amount of suspended debris, typical for EC, and papillary projections with increased vascularity. These echographic characteristics are similar to those of malignant ovarian tumors. Surgical interventions aimed to exclude the malignant ovarian tumors in patients with DEC are performed in almost $90 \%$ of observations [5, 6]. Unnecessary surgical interventions increase the risk to maternal and fetal health [7-11].

Thus, despite the fact that in pregnant women decidualization is characterized by benign course, it becomes the cause of numerous complications, and the presence of macroscopic features similar to those of malignant tumors may result in unnecessary therapeutic interventions.

The study was aimed to perform a differential diagnosis of DEC in pregnant women in order to define the rational treatment.

\section{METHODS}

A total of 82 female patients with endometriosis verified by histology were enrolled in the study, which was carried out in 2000-2021. The age of the patients examined varied between 19-41 years (the median age was 31 years). Inclusion criteria: consent to participate in the study; pregnancy; ultrasonography confirmed ovarian endometriosis in the pregravid period or during pregnancy; subsequent surgical treatment and morphological verification. Exclusion criteria: pregnant woman's refusal to participate in the study; threatened abortion; intrauterine infection; prenatal injury identified before the study.
In group 1 (control group), ultrasound examination performed during pregnancy revealed no signs of decidualization in 63 patients out of 82. These patients had a caesarean delivery due to combined indications: endometriosis and breech presentation in 9 patients, acute fetal hypoxia in 10 patients, unprepared birth canal and hypotonic labor in 11 patients, postterm pregnancy and threats to the fetus in 10 patients, severe preeclampsia in 4 patients, symphysitis in 5 patients, uterine scar in 6 patients, placenta praevia in 4 patients, primary infertility and in vitro fertilization (IVF) in 4 patients. After the delivery and histological examination of ovarian masses (OM), decidualization in the ovaries was the finding revealed in 43 of these patients.

Among 63 deliveries, 5 (7.9\%) were preterm. Of those in 1 case severe preeclampsia developed at 29 weeks, and the treatment was ineffective; in 2 cases at 32 weeks there were placenta previa with hemorrhage (1 patient) and premature rupture of membranes (PROM) (1 patient); in 2 cases at 35-36 weeks there were placenta previa with hemorrhage (1 patient) and acute fetal hypoxia (1 patient).

In 16 patients of group 2, decidualization in the ovary was found at 16-28 weeks (the median value was 17) of pregnancy, having the signs resembling malignization, that is why laparoscopic adnexectomy (one case) with oophorectomy (four cases) was performed, as well as laparotomy with adnexectomy (four cases) and oophorectomy (seven cases). When performing laparotomy, the abdominal cavity revision was performed, together with tissue specimen collection and rapid morphological examination.

Three patients had the severe decidual reaction and rare complications of endometriosis. In one patient, who had the caesarian delivery, endometrial implants were found during the surgical procedure. The foci of deciduosis were located on the uterine surface, omentum, peritoneum, and were represented by numerous yellowish elastic nodules of various sizes, the largest of which were almost $4 \mathrm{~cm}$ in diameter. In two women, decidualization was diagnosed in the colon wall, resected on days 2 and 5 after delivery due to the symptoms of acute abdomen.

When performing a differential diagnosis of DEC, we used the earlier results (control group 2) [12] obtained for 10 patients with ovarian serous papillary borderline tumors.

Ultrasound examination was performed with the Voluson E8 ultrasound machine (General Electric; USA) with the use of

ROC curve

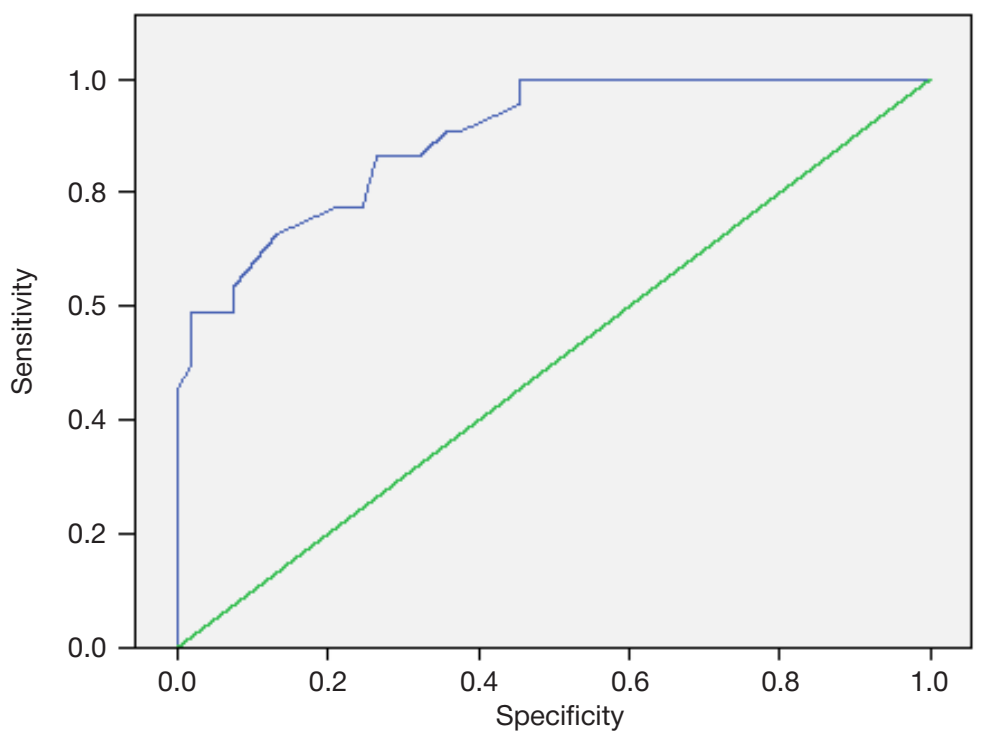

Fig. 1. ROC curve of the model for identification of endometrial cysts 
transabdominal and transvaginal color Doppler imaging and pulsed wave Doppler velocimetry. Ultrasound characteristics of the tumors were assessed using the earlier proposed models [13]. The 2D and 3D comprehensive ultrasound examination was combined with color Doppler (CD) and power Doppler (PD), as well as with 3D angiography. Diagnostic ultrasound was performed with the use of our proposed model, allowing one to distinguish between benign, borderline and malignant tumors [13]. When assessing the model accuracy, sensitivity (Se) and specificity (Sp) were used along with the count of correct assignments.

The concentration of CA-125 was assessed by enzyme immunoassay using the test system (Siemens; Germany).

$\mathrm{RMI}$ was defined in accordance with the guidelines [14, 15] using the following formula:

$$
\mathrm{RMI}=\mathrm{M} \times \mathrm{U} \times \mathrm{CA}-125,
$$

where $\mathrm{M}$ - menopausal status in points, $U$ - ultrasound results in points, C - serum CA-125 level (IU/mL).

$\mathrm{RMI} \geq 200$ was regarded as a sign of the high likelihood of epithelial ovarian cancer.

Tissue specimens stained with hematoxylin and eosin were assessed by different pathologists. Morphological diagnosis was established in accordance with the WHO classification of tumours of the female reproductive organs (2014). Paraffin-embedded tissue blocks were selected for immunohistochemistry: 15 blocks from patients with EC, and 10 blocks from patients with DEC. Morphological assessment was performed by standard methods. The diagnosis of deciduosis was confirmed by immunohistochemistry with the use of Vimentin (3B4, Ventana) and CD10 (56C6, Ventana) antibodies, being the markers of mesenchymal tissue and endometrial stroma, respectively. Intestinal tissue specimens were used as a positive control when assessing the expression of Vimentin, and the tonsillar tissue specimens were used when studying the CD10 immunoreactivity; when performing immunohistochemistry, the samples of the studied tissue not treated with primary antibodies were used as a negative control for both markers. Positive staining for both markers was subjectively classified as weak, moderate, or strong.

In addition, medical records together with the pregnancy and childbirth outcomes were studied in these 82 patients after treatment.

Statistical data processing was carried out using the SPSS 15.0 software package (IBM; USA). The data were subjected to frequency analysis by constructing the crosstabs. The differences were considered significant when $p<0.05$.

\section{RESULTS}

Ultrasonography showed that in the majority of observations in group 1 , EC $(n=63)$ were small, located inside the ovaries, with smooth outer and inner contours, the cyst content was of moderate or high echogenicity, blood vessels were visible in the walls. A total of 60 EC (95\%) were unilateral: right-sided in 18 patients (30\%), left-sided in 42 patients (70\%). Bilateral cysts were found in three observations (5\%).

The cyst size varied between $25 \times 20$ and $127 \times 83 \mathrm{~mm}$, the average size was $47.5 \pm 4.8 \times 31.8 \pm 3.1 \mathrm{~mm}$, (the median value was $41.5 \times 28.5 \mathrm{~mm})$. In 48 pregnant women $(76 \%)$ of group 1, EC had the characteristic echographic features (lied in a fixed position close to the posterior uterine wall, had a thickened wall, creating the effect of double contour, nonmovable finely dispersed suspended material (ground-glass opacity)), not differing substantially from the typical echographic features observed in the non-pregnant state. CD and PD

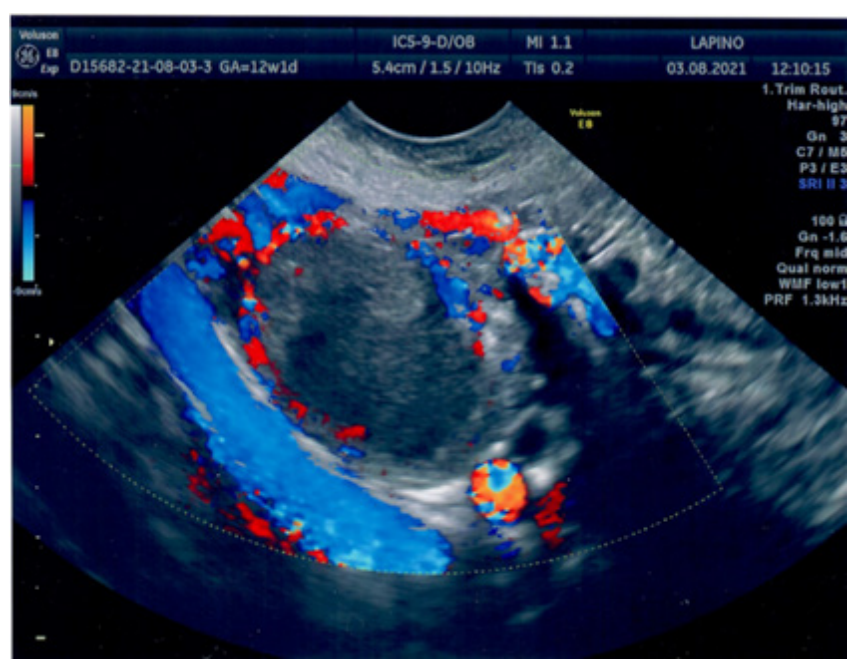

Fig. 2. Doppler ultrasonography of the endometrial cyst. Longitudinal transabdominal scan. Multiple coloured loci of blood flow and low resistive index values

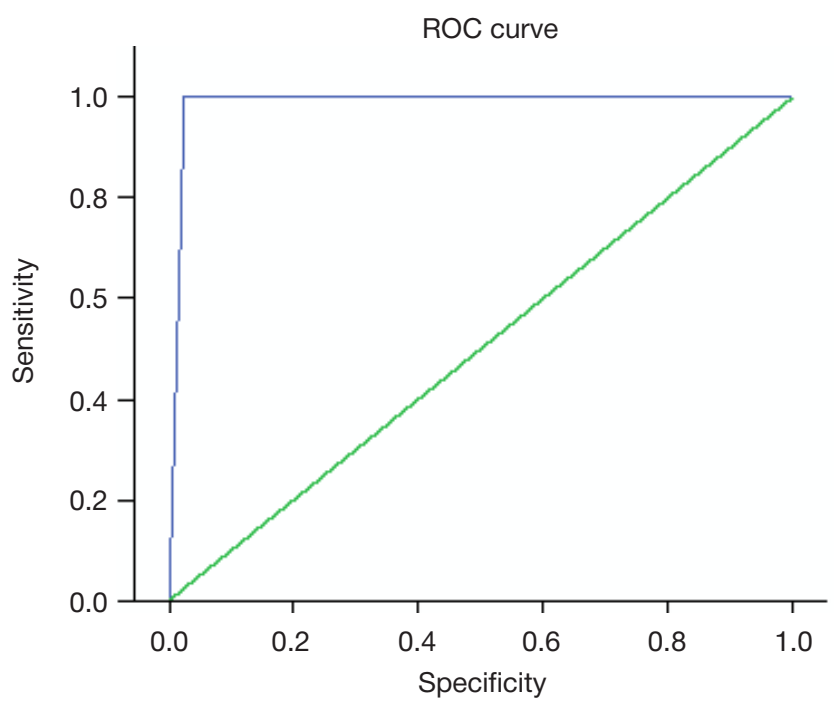

Fig. 3. ROC curve of the model for diagnosis of malignant and borderline tumors in pregnant women

revealed the sporadic coloured loci with high or medium resistance blood flow within a cyst wall. Bilateral cysts were found in three observations. In about $5 \%$ of 63 observations, EC had intracystic masses of moderate or high echogenicity in the form of blood clots and multiple sponge-like zones with undulating contour in the inner surface of the mass. In 12 observations (19\%), EC visible on the image looked like serous cystadenomas, round shaped hypoechoic masses with small amount of suspended material, avascular on CD images.

When performing the differential diagnosis of EC with the use of our proposed method [13], the patient's age, blood vessel arrangement, and the resistive index (RI) were of the greatest informational value. The maximum EC score obtained using the decision procedure did not exceed 2 points.

Performance of the model for EC identification (Fig. 1) was $84 \%$, however, the area under the ROC curve was very large, indicating the high quality of the model.

Preoperative evaluation of the patients in group 1 revealed no peculiarities in the ultrasound imaging parameters, CA-125, $\mathrm{RMI}$ in puerperant women with no deciduosis and those who had deciduosis, which was identified as a finding when performing the histological examination.

Blood levels of CA-125 in patients varied between 7.3 and $131.2 \mathrm{U} / \mathrm{mL}$, the average level was $61.1 \pm 8.5 \mathrm{U} / \mathrm{mL}$ 

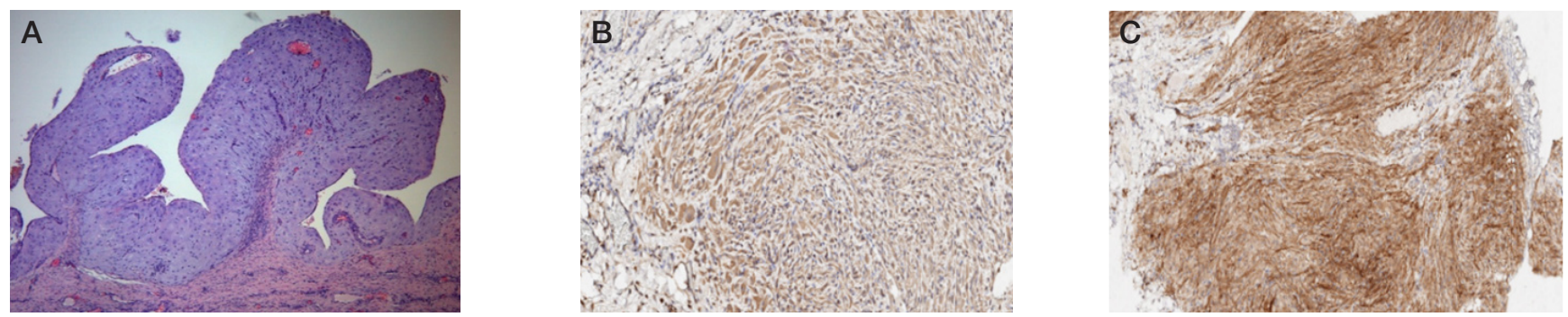

Fig. 4. Endometrial cyst with prominent decidualization and the formation of pseudopapillary structures. A. DEC (hematoxylin and eosin, $\times 50)$. B. CD10 prominent diffuse membranous and cytoplasmic expression. C. Vimentin — prominent diffuse cytoplasmic expression

(the median value was $53 \mathrm{U} / \mathrm{mL}$ ). Furthermore, in 19 patients (30\%), this value was below the threshold (7.3-33.4 U/mL). In 31 patients (49\%), this indicator showed the upward trend (44-94 U/mL), and in 13 patients (21\%) the value exceeded $100 \mathrm{U} / \mathrm{mL}(100.2-131.2 \mathrm{U} / \mathrm{mL})$. Our records show that CA-125 varies in the range of $8.5-280 \mathrm{U} / \mathrm{mL}$ during normal pregnancy (the median value is $95.6 \mathrm{U} / \mathrm{mL}$ ).

RMI varied between 7.3 and 131.2 , the average value was $65.4 \pm 9$ (the median value was 59). In the group of patients with EC, about $98 \%$ had RMl of less than 200. Moreover, in 19 patients (31\%), RMI was below 25, in 28 patients (44\%), it was $25-100$, and only in 16 patients (25\%), the observed RMl values exceeded 100, but never reached 200.

The planned caesarean section results in this group were as follows: all children were born in satisfactory condition. The Apgar score was 6-8 (the median value was 7.8) in premature babies and 8-9 (the median value was 8.9) in full-term babies. The birth weight was 1880-2840 $\mathrm{g}$ (the median value was 2640 $\mathrm{g}$ ) in premature babies and 2660-4480 g (the median value was $3530 \mathrm{~g})$ in full-term babies. Three premature babies needed the 2nd stage developmental care. In other babies, the early neonatal period went smoothly, the patients and their babies were discharged from the maternity hospital on day 5-7 after surgery. The morbidity rate was $3.2 \%$.

Morphological examination of non-decidualized EC showed that the walls of ovarian cysts consisted of ovarian Table. Comparative characteristics of EC, DEC and borderline tumors tissue with fibrotic changes, inner layer of cytogenic stroma with hemorrhages and hemosiderin deposition, and the lining epithelium was of endometrioid type. In DEC identified as findings, the fragments of the cystic ovarian endometrioma wall were defined with no lining epithelium, large areas of decidualization involving hypertrophy of endometrial stromal cells into polygonal cells with clear margins, abundant eosinophilic cytoplasm, round to oval nuclei with fine granular chromatin; no mitosis was detected.

When performing ultrasound examination in group $2(n=16)$, DEC were identified as the masses secured to the walls of the pelvis, located low relative to the gravid uterus. In 10 pregnant women (62.5\%), DEC were unilateral, right-sided DEC were found in 7 patients (70\%), and left-sided DEC were identified in three patients $(30 \%)$. Bilateral ovarian lesions were reported in six observations (37.5\%).

The cyst size varied between $20 \times 30$ and $108 \times 161 \mathrm{~mm}$, the average size was $73.7 \pm 6.2 \times 96.5 \pm 7.5 \mathrm{~mm}$ (the median value was $76.5 \times 108.5 \mathrm{~mm}$ ) (significant differences with group 1 , $p<0.001-0.05)$.

DEC were characterized by cystic and solid ovarian mass structure in all observations, multiloculated structure in four patients $(25 \%)$, or incomplete septa in four observations (25\%), irregular wall thickening with highly vascularized mural structures having multiple coloured loci of blood flow and low resistive index values in all masses.

\begin{tabular}{|c|c|c|c|}
\hline Studied parameters & EC & DEC & Borderline tumors \\
\hline Location of the mass & $\begin{array}{l}\text { Posterior to the uterus, } \\
\text { fixed low }\end{array}$ & $\begin{array}{l}\text { Posterior to the uterus, fixed } \\
\text { low }\end{array}$ & $\begin{array}{l}\text { Beside the uterus, often at the level of } \\
\text { the fundus }\end{array}$ \\
\hline Structure: cystic, cystic and solid & Cystic & Cystic and solid & Cystic and solid \\
\hline $\begin{array}{l}\text { Type of suspended debris: coarse echogenic } \\
\text { (ground-glass opacity), finely dispersed echogenic }\end{array}$ & $\begin{array}{l}\text { Ground-glass opacity - } \\
\text { coarse echogenic }\end{array}$ & $\begin{array}{l}\text { Ground-glass opacity - } \\
\quad \text { coarse echogenic }\end{array}$ & Finely dispersed echogenic \\
\hline Structure: unilocular, bilocular, trilocular & Unilocular & Unilocular, bilocular, trilocular & Unilocular, bilocular, trilocular \\
\hline Wall of the mass: thickness, size of altered locus & Fragmented up to $2 \mathrm{~mm}$ & Total up to $3-6 \mathrm{~mm}$ & Fragmented up to $2 \mathrm{~mm}$ \\
\hline Papillary growths: presence and shape & No & Regular round shape in $100 \%$ & $\begin{array}{l}\text { Irregular shape in } 100 \% \text { (of cauliflower } \\
\text { type) }\end{array}$ \\
\hline $\begin{array}{l}\text { Avascular echogenic inclusions with blurry } \\
\text { contour }\end{array}$ & Extremely rare & Up to $97 \%$ & No \\
\hline $\mathrm{RI}$ (resistive index) & $0.54(0.41-0.69)$ & $0.44(0.24-0.62)$ & $0.42(0.19-0.58)$ \\
\hline PSV (peak systolic velocity) & $9.6(9.2-14.3)$ & $13.2(6.0-17.0)$ & $14(3.9-21.9)$ \\
\hline PI (pulsatility index ) & $0.82(0.51-1.22)$ & $0.55(0.25-0.87)$ & $0.54(0.27-0.88)$ \\
\hline Blood circulation (arrangement of blood vessels) & No, single loci & $\begin{array}{l}\text { Moderate to high circulation } \\
\text { intensity }\end{array}$ & $\begin{array}{l}\text { High circulation intensity in the wall, } \\
\text { septa, and papillary growths }\end{array}$ \\
\hline Ascites & no & no & present in $60 \%$ \\
\hline $\mathrm{CA}-125(\mathrm{U} / \mathrm{mL})$ & $61.1 \pm 8.5($ median 53$)$ & $120 \pm 31.6($ median 70.5$)$ & $135.4 \pm 55.1$ (median 80.5) \\
\hline RMI & $65.4 \pm 9$ (median 59) & $348 \pm 97$ (median 212) & $334.1 \pm 147$ (median 241.5) \\
\hline Histological examination & $\begin{array}{l}\text { Histological features of } \\
\text { ovarian EC }\end{array}$ & $\begin{array}{c}\text { Histological features of ovarian } \\
\text { DEC }\end{array}$ & $\begin{array}{l}\text { Histological features of ovarian serous } \\
\text { papillary borderline tumors }\end{array}$ \\
\hline
\end{tabular}


When performing the differential diagnosis of DEC with the use of our proposed method [13], such factors as ovarian tissue, RI, PSV, and blood vessel arrangement were of great prognostic value. The maximum DEC score obtained using the decision procedure exceeded 4 points. Based on the ultrasound features, DEC (Fig. 2) could be identified as a malignant tumor.

The model obtained showed sensitivity of $100 \%$ and specificity of $92.3 \%$ in the test sample, with the overall accuracy of $92.8 \%$ (Fig. 3).

Blood levels of CA-125 in patients of group 2 varied between 17.6 and $361 \mathrm{U} / \mathrm{mL}$, the average level was $120.1 \pm$ $31.6 \mathrm{U} / \mathrm{mL}$ (the median value was $70.5 \mathrm{U} / \mathrm{mL}$ ). Furthermore, in two pregnant women (12.5\%), this value was below the threshold, in nine observations (56.25\%), this indicator showed the upward trend (from 47.8 to $82.67 \mathrm{U} / \mathrm{mL}$ ), and in five patients $(31.25 \%)$, the value exceeded the threshold and reached $361 \mathrm{U} / \mathrm{mL}$.

RMI varied between 69 and 1083, the average value was $348 \pm 97$ (the median value was 212, $p<0.001-0.05$ ). In the group of patients with DEC, seven pregnant women (43.75\%) had RMI values significantly higher than 200 (207-1083), five patients (31.25\%) had RMI not exceeding 200 , and only four patients (25\%) had RMl values below 100 .

In patients of group 2 with decidualization in the ovary, pregnancy evolved in different ways. In four patients out of 16 (25.0\%), pregnancy was complicated by miscarriage after the surgical treatment due to suspected malignancy, performed at week 12-27 of pregnancy. Perinatal death at 23 weeks of gestation occurred in one patient, three patients gave birth prematurely, and 12 patients had a full term delivery. The Apgar scores of premature babies varied between 6-8 and 7-8 (the median value was 6-7). The birth weight of premature babies was 1880-2640 g, (the median value was $2010 \mathrm{~g}$ ). In patients, who had a full term delivery, the Apgar scores of the newborns varied between 8-9 and 9-9 (the median value was 8-9), the Silverman Anderson score was 2-3, and the birth weight was 2810-3720 g (the median value was 3185 g). In one observation, the early neonatal period was spent in the intensive care unit, and in three observations, respiratory support and the treatment of respiratory distress syndrome were required. Subsequently, three newborns were transferred to the multidisciplinary children's hospital for the 2nd stage developmental care. Thus, perinatal mortality in group 2 was $62.5 \%$, and morbidity was $25.0 \%$.

Fig. 4A demonstrates the wall of the cystic ovarian endometrioma with no lining epithelium, fibrotic changes of ovarian tissue, and prominent hypertrophy of endometrial stromal cells with the formation of the well vascularized papillary structures.

Immunohistochemistry performed in the group 2 on 10 selected paraffin-embedded tissue blocks confirmed decidualization in the cystic ovarian endometrioma walls in all observations. Morphological evaluation showed that the latter had a typical structure, were lined with epithelium of endometrioid type, with hemorrhagic foci and hemosiderin deposition within the wall. Immunohistochemistry revealed moderate positive cytoplasmic expression of CD10 in the stromal cells of the foci with decidualization (Fig. 4B) together with strong positive cytoplasmic immunoreactivity for Vimentin (Fig. 4C).

\section{DISCUSSION}

When reviewing the data obtained, it should be noted that EC with no prominent decidualization during pregnancy have

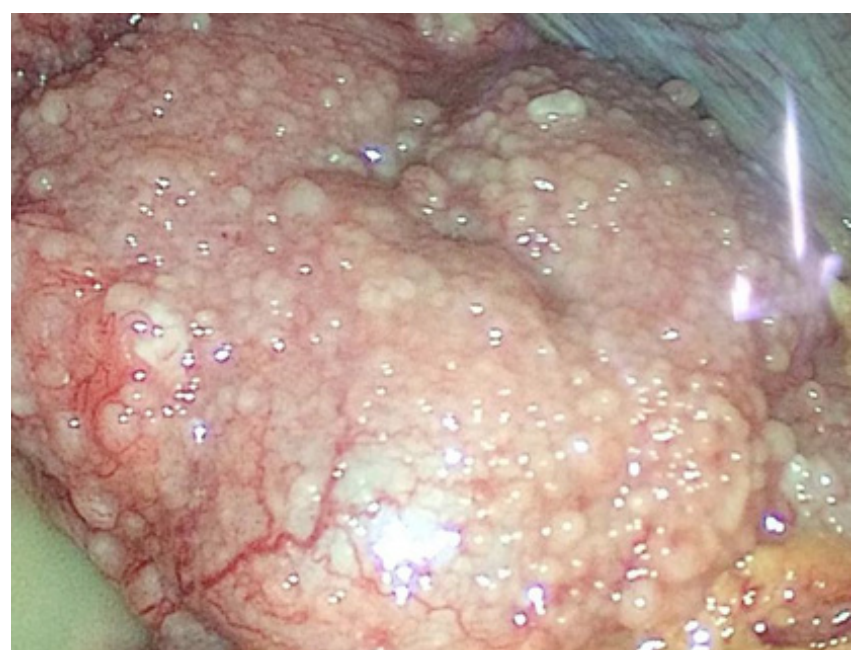

Fig. 5. Multiple regions of decidualization

a latent favorable course and do not result in pathological pregnancy and labor course, increased perinatal morbidity and mortality.

According to literary sources, decidualized EC occurs in $12-20 \%$ of observations; the cyst size is reduced in $52 \%$ of observations, increased in $20 \%$ of observations, and unaffected in $28 \%$ of observations. Furthermore, the rate of DEC rupture is $3-4 \%$, and the abscess formation is revealed in $4 \%$ of observations [16, 17].

Differential diagnosis of ovarian EC and DEC in pregnant women remains an obstetric challenge. Most authors distinguish the combination of the cystic cavity with a large amount of suspended debris, typical for EC, and papillary projections with increased vascularity among the echographic signs of DEC [7-11]. When there is a DEC, the sonographic features are similar to those observed in patients with malignant ovarian tumors based on the echographic characteristics. Our records (Table) show that today the use of generally accepted non-invasive preoperative diagnostic tests makes it possible to distinguish between EC, DEC, and borderline tumors with a high probability. The comparison of DEC with borderline tumors (with the control group 2) revealed significant fluctuations in the studied indicators, however, based on the ultrasound imaging data, these were distinguishable in the majority of observations. In modern medicine, the good test (marker) is the one that is not found in $70 \%$ of the comparison group when comparing two groups.

When performing the differential diagnosis of the studied groups (Table), the following ultrasound imaging parameters were the most valuable: the altered mass wall thickness, the existence and shape of papillary masses, avascular echogenic inclusions with blurry contour, blood circulation and arrangement of blood vessels, ascites. The frequency analysis showed that the DEC group differed from the groups with EC and borderline tumors in $60-100 \%$ of observations based on the sonographic markers. The results of histological examination made it possible to perform a differential diagnosis of EC, DEC, and borderline tumors in $100 \%$ of observations.

Given that the assessment of the studied sonographic markers is still subjective, and the findings have made it impossible to eliminate the high risk of the mass malignization in patients with DEC, these patients have undergone surgery in early pregnancy. Echographic image of DEC suspicious for malignization has made it impossible to prolong pregnancy for ethical reasons, even with the possibility of the increased rate of perinatal complications. The need for surgical treatment 
aimed to exclude the malignant ovarian tumors in patients with decidualized EC (DEC) is in line with literature data $[5,6]$, this treatment method is applied in almost $90 \%$ of observations.

Adverse pregnancy outcomes in patients with endometriosis relate primarily to miscarriage, high risk of preterm labor and low birth weight babies [18-20].

Pregnancy and labor in patients with endometriosis are associated with high risk of complications, such as hemoperitoneum, bowel perforation, appendicitis, and EC rupture [19, 20].

Other complications of pregnancy are observed in patients with decidualization. Thus, in one of the trials, histological examination revealed decidual changes in all layers of appendix on day 5 after caesarian section and gangrenous appendicitis [21]. During our study, multiple yellowish elastic nodules of various size (up to $4 \mathrm{~cm}$ ), located on the uterine surface, omentum, and peritoneum, were found during the surgical procedure in one patient, who had caesarian section for obstetric reasons (Fig. 5).

The fragments of omentum were resected for further histological examination, which revealed prominent decidual changes. In the other two patients, we had to perform re-surgery during the postoperative period (on days $2-5$ after the caesarian section performed for obstetric reasons) due to acute abdomen. The macroscopically altered fragments of the colon with decidualization in the wall and multiple endometrioid heterotopias with decidual changes in all layers of the colon wall were resected.
There is evidence of similar immunohistochemistry features in the extrauterine mesenchymal cells that have undergone the decidual reaction, and decidualized endometrial stromal cells with positive expression of mesenchymal markers (Vimentin, Desmin), and progesterone receptors [22]. Reduced concentration of progesterone, resulting from pregnancy termination triggers the involution of foci with decidualization, which in some cases is followed by severe circulatory disorder and decidual tissue destruction, probably entailing the pain symptoms and hemorrhage [23, 24]. Intra-abdominal hemorrhage was revealed on day 7 after the caesarian section in the patient, having the focus with decidualization, located in the area of the uterine posterior wall on the left $[25,26]$.

Thus, decidualization in pregnant women is characterized by a benign course, however, it becomes the cause of numerous complications. The presence of macroscopic features similar to those of malignant tumors may result in unnecessary therapeutic interventions.

\section{CONCLUSIONS}

Currently, the diagnosis of DEC and the treatment of patients during pregnancy give rise to many questions. Further clinical observation and the search for more reliable methods of the DEC diagnosis and rational treatment in pregnant women are required.

\section{References}

1. Marino T, Craigo SD. Managing adnexal masses in pregnancy. Contemp Obstet Gynecol. 2000; 45: 130-43.

2. Kommos F, Pfisterer J, Peters F, et al. Ektope Dezidualreaktion möglicher Anlass zur kolposkopischen, histologischen und intraoperativen Fehldiagnose. Geburtsh Frauenheilk. 1998; 58: 446-50.

3. Adhikari LJ, Rulong SR. Florid diffuse peritoneal deciduosis mimicking carcinomatosis in a primigravida patient: a case report and review of the literature. Int J Clin Exp Pathol. 2013; 6 (11): 2615-9.

4. Meresman GF, Auge L, Baranao Rl, et al. Oral contraceptives suppress cell proliferation and enhance apoptosis of eutopic endometrial tissue from patients with endometriosis. Fertil Steril. 2002; 77: 1141-7.

5. Pateman K, Moro F, Mavrelos D, et al. Natural history of ovarian endometrioma in pregnancy. BMC Womens Health. 2014; 14: 128.

6. Leone Roberti Maggiore U, Ferrero S, Mangili G, et al. A systematic review on endometriosis during pregnancy: diagnosis, misdiagnosis, complications and outcomes. Hum Reprod Update. 2016; 22 (1): 70-103.

7. Groszmann Y, Howitt BE, Bromley B, Feltmate CM, Benacerraf BR. Decidualized endometrioma masquerading as ovarian cancer in pregnancy. J Ultrasound Med. 2014; 33 (11): 1909-15. DOI: 10.7863/ultra.33.11.1909.

8. Bailleux M, Bernard JP, Benachi A, Deffieux X. Ovarian endometriosis during pregnancy: a series of 53 endometriomas. Eur J Obstet Gynecol Reprod Biol. 2017; 209: 100-4. DOI: 10.1016/j.ejogrb.2015.09.037.

9. Mascilini F, Moruzzi C, Giansiracusa C, et al. Imaging in gynecological disease. 10: Clinical and ultrasound characteristics of decidualized endometriomas surgically removed during pregnancy. Ultrasound Obstet Gynecol. 2014; 3 (44): 354-60.

10. Barbieri M, Somigliana E, Oneda S, et al. Decidualized ovarian endometriosis in pregnancy: a challenging diagnostic entity. Hum Reprod. 2009; 8 (24): 1818-24.

11. Graupera B, Pascual M, Hereter L, et al. Dezidualization of endometrioma during pregnancy mimicking a malignant ovarian tumor. Ultrasound Obstet Gynecol. 2013; 42 (S1): 71.

12. Ashrafjan LA, Kurcer MA, Gerasimova AA, Klimenko PA Pogranichnye i zlokachestvennye opuholi jaichnikov vo vremja beremennosti. Onkoginekologija. 2019; 3 (31): 68-77. Russian.

13. Gerasimova AA, Shvyrev SL, Solomatina AA, Gus Al, Klimenko PA. Sposob vyjavlenija haraktera jaichnikovyh obrazovanij. Onkologija. 2013; 1; 34-40. Russian.

14. Tingulstad S, Hagen B, Skjeldestad FE, et al. Evaluation of a risk of malignancy index based on serum CA125, ultrasound findings and menopausal status in the preoperative diagnosis of pelvic masses. Brit. J. Obstet. Gynaecol. 1996; 103 (8): 826-31.

15. Jacobs I, Oram D, Fairbanks J, et al. A risk of malignancy index incorporating CA125, ultrasound and menopausal status for the accurate pre-operative diagnosis of ovarian cancer. Brit J Obstet Gynaecol. 1990; 97; 922-9.

16. Bulanov MN, Gorta RN. Ul'trazvukovoe issledovanie jendometrioidnyh kist jaichnikov vo vremja beremennosti. Ul'trazvukovaja i funkcional'naja diagnostika. 2015; 1: 55-71. Russian.

17. Bromley B, Benacerraf B. Adnexal masses during pregnancy: accuracy of sonographic diagnosis and outcome. J Ultrasound Med. 1997; 7 (16); 447-52.

18. Ueda $Y$, Enomoto T, Miyatake $T$, et al. A retrospective analysis of ovarian endometriosis during pregnancy. Fertil Steril. 2010; 94 (1): $78-84$.

19. Fruscella E, Testa AC, Ferrandina G, et al. Sonographic features of decidualized ovarian endometriosis suspicious for malignancy. Ultrasound Obstet Gynecol. 2004; 5 (24): 578-80.

20. Carvalho LFP, Rossener R, Azeem A, et al. From conception to birth - how endometriosis affects the development of each stage of reproductive life Minerva Ginecol. 2013; 65 (2): 181-98.

21. Vercellini P, Parazzini F, Pietropaolo G, et al. Pregnancy outcome in women with peritoneal, ovarian and rectovaginal endometriosis: a retrospective cohort study. BJOG. 2012; 119 (12): 1538-43. DOI: 10.1111/j.1471-0528.2012.03466.x.

22. Papp Z, Petri I, Villányi E, Tiszlavicz L, Ugocsai G. Deciduosis causing perforating appendicitis in the early postpartum period following caesarean section. Orv Hetil. 2008; 149 (7): 329-31. DOI: 10.1556/OH.2008.28227.

23. Heatley MK, Maxwell P, Toner PG. The immunophenotype 
of human decidua and extrauterine decidual reactions. Histopathology. 1996; 29: 437-42.

24. Lockwood CJ, Kayisli UA, Stocco C, et al. Abruption-induced preterm delivery is associated with thrombin-mediated functional progesterone withdrawal in decidual cells. Am J Pathol. 2012; 181: 2138-48. DOI: 10.1016/j.ajpath.2012.08.036.

25. Lier $\mathrm{MCl}$, Brosens IA, Mijatovic V, Habiba M, Benagiano G.

\section{Литература}

1. Marino T, Craigo SD. Managing adnexal masses in pregnancy. Contemp Obstet Gynecol. 2000; 45: 130-43.

2. Kommos F, Pfisterer J, Peters F, et al. Ektope Dezidualreaktion möglicher Anlass zur kolposkopischen, histologischen und intraoperativen Fehldiagnose. Geburtsh Frauenheilk. 1998; 58: 446-50.

3. Adhikari LJ, Rulong SR. Florid diffuse peritoneal deciduosis mimicking carcinomatosis in a primigravida patient: a case report and review of the literature. Int J Clin Exp Pathol. 2013; 6 (11): 2615-9.

4. Meresman GF, Auge L, Baranao Rl, et al. Oral contraceptives suppress cell proliferation and enhance apoptosis of eutopic endometrial tissue from patients with endometriosis. Fertil Steril. 2002; 77: 1141-7.

5. Pateman K, Moro F, Mavrelos D, et al. Natural history of ovarian endometrioma in pregnancy. BMC Womens Health. 2014; 14 128.

6. Leone Roberti Maggiore U, Ferrero S, Mangili G, et al. A systematic review on endometriosis during pregnancy: diagnosis, misdiagnosis, complications and outcomes. Hum Reprod Update. 2016; 22 (1): 70-103

7. Groszmann Y, Howitt BE, Bromley B, Feltmate CM, Benacerraf BR. Decidualized endometrioma masquerading as ovarian cancer in pregnancy. J Ultrasound Med. 2014; 33 (11): 1909-15. DOI: 10.7863/ultra.33.11.1909

8. Bailleux M, Bernard JP, Benachi A, Deffieux X. Ovarian endometriosis during pregnancy: a series of 53 endometriomas. Eur J Obstet Gynecol Reprod Biol. 2017; 209: 100-4. DOI: 10.1016/j.ejogrb.2015.09.037.

9. Mascilini F, Moruzzi C, Giansiracusa C, et al. Imaging in gynecological disease. 10: Clinical and ultrasound characteristics of decidualized endometriomas surgically removed during pregnancy. Ultrasound Obstet Gynecol. 2014; 3 (44): 354-60.

10. Barbieri M, Somigliana E, Oneda S, et al. Decidualized ovarian endometriosis in pregnancy: a challenging diagnostic entity. Hum Reprod. 2009; 8 (24): 1818-24.

11. Graupera B, Pascual M, Hereter L, et al. Dezidualization of endometrioma during pregnancy mimicking a malignant ovarian tumor. Ultrasound Obstet Gynecol. 2013; 42 (S1): 71.

12. Ашрафян Л. А., Курцер М. А., Герасимова А. А., Клименко П. А. Пограничные и злокачественные опухоли яичников во время беременности. Онкогинекология. 2019; 3 (31): 68-77.

13. Герасимова А. А., Швырев С. Л., Соломатина А. А., Гус А. И., Клименко П. А. Способ выявления характера яичниковых образований. Онкология. 2013; 1; 34-40.

14. Tingulstad S, Hagen B, Skjeldestad FE, et al. Evaluation of a risk
Decidual bleeding as a cause of spontaneous hemoperitoneum in pregnancy and risk of preterm birth. Gynecol Obstet Invest. 2017; 82 (4): 313-21. DOI: 10.1159/000468933.

26. Lüdders DW, Henke RP, Saba M, et al. Severe maternal preand postpartum intra-abdominal bleeding due to deciduosis. Geburtshilfe Frauenheilkd. 2015; 75 (3): 259-62. DOI: 10.1055/s0035-1545876.

of malignancy index based on serum CA125, ultrasound findings and menopausal status in the preoperative diagnosis of pelvic masses. Brit. J. Obstet. Gynaecol. 1996; 103 (8): 826-31.

15. Jacobs I, Oram D, Fairbanks J, et al. A risk of malignancy index incorporating CA125, ultrasound and menopausal status for the accurate pre-operative diagnosis of ovarian cancer. Brit $\mathrm{J}$ Obstet Gynaecol. 1990; 97; 922-9.

16. Буланов М. Н., Горта Р. Н. Ультразвуковое исследование эндометриоидных кист яичников во время беременности. Ультразвуковая и функциональная диагностика. 2015; 1: 55-71.

17. Bromley B, Benacerraf B. Adnexal masses during pregnancy: accuracy of sonographic diagnosis and outcome. J Ultrasound Med. 1997; 7 (16); 447-52.

18. Ueda $\mathrm{Y}$, Enomoto T, Miyatake $\mathrm{T}$, et al. A retrospective analysis of ovarian endometriosis during pregnancy. Fertil Steril. 2010; 94 (1): 78-84.

19. Fruscella E, Testa AC, Ferrandina G, et al. Sonographic features of decidualized ovarian endometriosis suspicious for malignancy. Ultrasound Obstet Gynecol. 2004; 5 (24): 578-80.

20. Carvalho LFP, Rossener R, Azeem A, et al. From conception to birth - how endometriosis affects the development of each stage of reproductive life Minerva Ginecol. 2013; 65 (2): 181-98.

21. Vercellini P, Parazzini F, Pietropaolo G, et al. Pregnancy outcome in women with peritoneal, ovarian and rectovaginal endometriosis: a retrospective cohort study. BJOG. 2012; 119 (12): 1538-43. DOI: 10.1111/j.1471-0528.2012.03466.x.

22. Papp Z, Petri I, Villányi E, Tiszlavicz L, Ugocsai G. Deciduosis causing perforating appendicitis in the early postpartum period following caesarean section. Orv Hetil. 2008; 149 (7): 329-31. DOI: $10.1556 / \mathrm{OH} .2008 .28227$.

23. Heatley MK, Maxwell P, Toner PG. The immunophenotype of human decidua and extrauterine decidual reactions. Histopathology. 1996; 29: 437-42.

24. Lockwood CJ, Kayisli UA, Stocco C, et al. Abruption-induced preterm delivery is associated with thrombin-mediated functional progesterone withdrawal in decidual cells. Am J Pathol. 2012; 181: 2138-48. DOI: 10.1016/j.ajpath.2012.08.036.

25. Lier $\mathrm{MCl}$, Brosens IA, Mijatovic V, Habiba M, Benagiano G. Decidual bleeding as a cause of spontaneous hemoperitoneum in pregnancy and risk of preterm birth. Gynecol Obstet Invest. 2017: 82 (4): 313-21. DOI: 10.1159/000468933.

26. Lüdders DW, Henke RP, Saba M, et al. Severe maternal preand postpartum intra-abdominal bleeding due to deciduosis. Geburtshilfe Frauenheilkd. 2015; 75 (3): 259-62. DOI: 10.1055/s0035-1545876. 